IBIMA Publishing

IBIMA Business Review

https://ibimapublishing.com/articles/IBIMABR/2021/940105/

Vol. 2021 (2021), Article ID 940105, 11 pages, ISSEN: 1947-3788

DOI: $10.5171 / 2021.940105$

Research Article

\title{
Transformation of Polish ICT Enterprises after the COVID 19
}

\author{
Katarzyna JASIŃSKA \\ Wrocław University of Economics, Wrocław, Poland \\ katarzyna.jasinska@ue.wroc.pl
}

Received date: 23 April 2021; Accepted date:3 March 2021; Published date: 2 August 2021

Academic Editor: Daiva Zostautiene

Copyright (C) 2021. Katarzyna JASIŃSKA. Distributed under Creative Commons Attribution 4.0 International CC-BY 4.0

\begin{abstract}
The COVID-19 epidemic has disrupted the development of the global economy. Virtually all sectors experienced a negative impact, which forced the transformation of many enterprises. In the case of the ICT sector, new environmental conditions pose a threat but also a development perspective, which forces ICT enterprises to introduce cross-cutting changes within their activities. These changes are not limited to the ICT sector but affect other economic sectors. This is related to the role that the ICT sector plays in creating innovation, building modern business models and new phenomena in the information society. The aim of the article is an attempt to characterize the conditions related to the transformation of ICT companies caused by the COVID-19 epidemic. The first part of the article defines the basic concepts of the ICT sector and characterizes its importance for the development of the economy. Then, against the background of the evolution of the ICT sector, the general characteristics of changes taking place within it are discussed. The next part of the article presents the results of the author's own research conducted among enterprises from the Polish ICT sector in 2020. The last part contains conclusions.
\end{abstract}

Keywords: ICT Market, IT Market, Strategic Directions, Covid Crisis

\section{Introduction}

The ICT sector is described as a driving force for the development of the global economy [Shamim 2007; Garcia-Muniz, Vicante 2014; Sassi, Goaied 2013; WEF 2009; WEF 2015]. Investments in development and innovation contribute to the increase in the effectiveness of enterprises and build their intellectual capital. Enterprises in stock market reports bid on development ideas related to the implementation of new technologies, building a vision of future profits for investors. There is even a new term for an enterprise that builds its competitiveness based on new technologies - the so-called digital leader. This picture presented the participants of the ICT sector perspectives of undisturbed growth, dependent only on the company's ability to follow changing technological trends. The COVID-19 epidemic has shaken the global economy, which has faced technology providers with a natural question about the timeliness of development directions defined so far. The

Cite this Article as: Katarzyna JASIŃSKA (2021)," Transformation of Polish ICT Enterprises after the COVID 19 ", IBIMA Business Review, Vol. 2021 (2021), Article ID 940105, DOI: 10.5171/2021.940105 
purpose of this article is to attempt to approximate the conditions in which ICT enterprises currently find themselves, and to indicate how enterprises respond to changes.

It should be emphasized that there is currently no detailed data available on the impact of the epidemic crisis on the ICT sector. In the global context, the first forecasts are created in selected market segments, and in the local context preliminary research is being conducted [KIGEiT, 2020; IDC 2020]. They have an undoubted cognitive dimension, but in a practical context they do not have a broader meaning. The goal chosen in the article fits in with this trend, while maintaining concentration primarily on managerial rather than macroeconomic aspects, which is typical of most available studies.

The first part of the article defines the concept of the ICT sector, then discusses its evolution and importance for the development of the economy. The general characteristics of changes taking place in the ICT sector are discussed further, and on this basis research hypotheses were formulated, which were verified in an indepth interview among 52 managers from 20 companies in the Polish ICT sector. The last part of the article presents the results of research and formulated conclusions.

\section{ICT sector and its economic importance}

The ICT sector has already been the subject of many different scientific publications and numerous reports [Shamim 2007; Lombard 2009; Garcia-Muniz, Vicante, 2014; Sassi, Goaied 2013; PARP 2017; IDC 2020]. This has contributed to the creation of very different ways of defining this sector [OECD 2011; Central Statistics Office 2010; PARP 2017; Zuppo, 2012; UNSC 2002]. An overview of the available definitions is not the purpose of this article, therefore, the basic sector definition created by the OECD. According to which, the ICT sector is defined as a set of enterprises conducting production and service activities, which consists in intercepting, sending and displaying data and information by electronic means [OECD 2002]. ICT sector is a combination of the IT sector (Information Technologies) and the telecommunications sector. According to the Gartner report, the size of the global ICT market was $\$ 3.7$ trillion in 2019. Over the past 10 years, the ICT sector has seen annual value increases of around 3\%. Among the most important market segments are: telecommunications services, equipment supplies, software development, data centers, and professional service providers [Gartner 2019]. In Poland, the situation of the ICT sector was described as stable. Since the beginning of 2014, GDP has been growing at a rate of at least 3.1\% per year, and the share of the ICT sector in GDP is about 8\% [PARP 2017].

ICT solutions are also a significant element of the Fourth Digital Revolution, which was distinguished by the World Economic Forum and Klaus Schwab. According to her concept, the boundaries between the physical world and ICT are becoming blurred and the saturation of IT solutions is constantly increasing [Schwab 2017].

According to the PARP report, the development of information technologies is the foundation of growth not only of the ICT sector, but also of the entire economy and society. The competitiveness of enterprises is largely based on the ability to use ICT sector solutions in the area of providing their own services or products [PARP 2017]. The role played by the ICT sector has been recognized not only in Europe; The World Economic Forum in cooperation with the Business School - INSEAD (INSEAD - The Business School for the World) measures the NRI (Networked Readiness Index), which can be defined as an indicator of readiness to use information technology communication in the economy of states [Stecyk 2009].

In the case of the ICT sector, there is a phenomenon of stimulating the growth of other economic fields, practically regardless of the economic profile of a given country, because the use of information and communication technologies leads to an increase in the efficiency of enterprises. However, this conclusion was not obvious, and was based on observations of the 
economies of strongly developing countries. In 1978, it was recognized that the widespread use of ICT was a source of success for the Japanese economy, and similar solutions began to be used in France. These activities became the foundation for building European strategies aimed at the development of the ICT sector, which, however, were not started until the 1990s [Grodzka 2009 p. in: Biuro Analiz Sejmowych 2009]. The widening technological divide between Europe, and Japan and the US led to the publication in 1994 of a set of recommendations for Europe and a global information society. Recommendations to the European Council (Europe and the Global Information Society) became the basis for shaping longterm strategies for the development of the ICT sector in Europe [http://ec.europa.eu/archives/ISPO/infoso c/ ..., date of download: 16/12/11].

The importance of the ICT sector for the development of the economy has increased over time, as the ability of enterprises to use products of this sector has increased. At the beginning of 2020, the ICT sector had prospects of almost unlimited growth.

General changes taking place in ICT enterprises in connection with the COVID - 19 epidemic

The difficult macroeconomic situation related to the COVID-19 epidemic, which became a global pandemic in March 2020, reduces the general willingness of enterprises to spend, instead inclining them to strive to accumulate cash and cut costs. According to the IDC, the situation is not dramatic, however, the increase in spending on ICT in Europe in 2020 will amount to only $1.4 \%$, which, compared to the December forecast that assumed $2.8 \%$, is a $50 \%$ decrease. The pessimistic scenario assumes an increase of only $0.2 \%$ [IDC 2020].

Quarantine and temporary stoppages of many enterprises caused a degree of stagnation of demand for goods and services. This negatively affects, above all, the sectors whose products are consumer in nature. In the case of the ICT sector, the situation is more complex because, although some development investments of enterprises have been frozen, other purchasing decisions have become even more meaningful during the crisis. This is due to the fact that the use of ICT in enterprises can also be a source of savings and lead to a reduction in human participation in the provision of services. This phenomenon places before the ICT sector not only threats but also opportunities, inaccessible to other sectors, which construct their products and services with a small share of intellectual capital. An important element of transformation will be the marketing strategy of enterprises. It can be assumed that there will be changes in the share of revenues in individual market segments.

Business models of services rendered may also be subject to change in adapting to changing demand conditions.

One of the most important areas of ICT enterprises' activity, thanks to which it is possible to provide services to clients, is project implementation.

One of the results of the aforementioned research conducted by the author in 2011 was to verify the impact of external factors on the success of projects in the ICT sector. Under stable environmental conditions in which the study was conducted, as many as $97 \%$ of respondents indicated that "the degree of stability of the environment in the social, economic and environmental dimensions" has a significant impact on the management of project implementation processes [Jasinska, Szapiro 2014]. It can therefore be assumed that the area of project implementation will undergo significant transformation in connection with the epidemic. Changes may include not only the way projects are implemented but also the management of entire portfolios and changes in the perception of value built by projects. The implementation of projects is based on teamwork, in which the competences of members play a special role.

Until now, the ICT market was definitely an employee's market, not an employer's one. The constant shortage of specialists led to 
above average wages and salaries recorded in the sector. So, the natural question arises as to how the crisis will affect staff in the sector. On the one hand, one can observe an increase in the number of projects, and a growing demand for specialists. On the other hand, however, some projects may freeze, which will result in less demand for highly qualified staff.

Leading players in the ICT sector in times of stable development took care of building the image as a professional entity that customers could rely on while implementing key projects for their business. In a crisis situation, building the right image is important for ICT companies. It should be remembered that ICT projects are often high-budget initiatives, forcing large expenses on clients. In the face of the progressing crisis, there is a natural expectation of the involvement of a trusted business partner in helping to solve current problems. In the image sphere, this is related to, for example, the implementation of social responsibility activities by ICT enterprises. Therefore, the question arises as to what type of activities are undertaken by ICT enterprises in the area of shaping their image in a crisis.

In the area of internal organization, the crisis associated with COVID-19 has had an influence in all industries, forcing a change in working methods, e.g., the introduction of telework and transferring some of the processes previously carried out in a traditional form to the digital environment. An important element for verification is, therefore, how to reorganize work in enterprises and prepare them to adapt to changes.

In summary, in Table 1, areas have been identified that are undergoing changes due to the impact of the COVID-19 epidemics. The areas have been assigned the forecast change trends. In this way, hypotheses were constructed and verified in empirical studies.

Table 1: Areas of the ICT enterprise and its surroundings susceptible to changes related to the COVID-19 crisis

\begin{tabular}{|l|l|l|}
\hline Area of change & Hypothesis: expected change trend \\
\hline H1 & Demand and willingness to spend & $\begin{array}{l}\text { Stagnation while maintaining the growth of selected } \\
\text { segments }\end{array}$ \\
\hline H2 & Market opportunities and development & $\begin{array}{l}\text { The emergence of new market opportunities. } \\
\text { Interruption of previously stable trends }\end{array}$ \\
\hline H3 & $\begin{array}{l}\text { Employment and demand for } \\
\text { specialists }\end{array}$ & Turbulence in the employment market \\
\hline H4 & Implementation of projects & Changes in the scope of projects and portfolios \\
\hline H5 & Company image & Take action to combat the epidemic \\
\hline H6 & Management and work methods & Digitization of processes and teleworking \\
\hline H7 & Willingness to implement changes & High readiness \\
\hline
\end{tabular}

The hypothesis presented in Table 1 ware built on the basis of market observations described in this part of the article, because the article was constructed in the beginning of the epidemic period.

\section{The Empirical Studies}

Trends indicated in Table 1, expressed in the form of a hypothesis, were verified in empirical studies. This study was conducted from April 10-17, 2020 and involved indepth interviews with 52 managers representing 20 companies from the Polish ICT sector. Companies were selected form the Polish Agency for Enterprise Development's list, that was presented in report "IT/ICT sector in Poland" [PARP, 2019]. The whole list included 200 companies. Only 20 of them responded. The study consisted of two parts. In the first stage, general questions were asked about the characterization of changes occurring in a given area of the enterprise and the market, and verified probable trends of changes, which are described in Table 1. In 
the second stage, deeper questions were asked to induce the respondent to think about the opportunities and threats, the reasons for the changes, and long-term impact of the diagnosed events on the enterprise.

The survey was completed by respondents whose characteristics are presented in Table 2.

Table 2: Share of respondents in the knowledge broken down by type of enterprise

\begin{tabular}{|c|c|c|c|c|}
\hline Company & $\begin{array}{l}\text { Number } \\
\text { of } \\
\text { companie } \\
\text { s }\end{array}$ & $\begin{array}{l}\text { percentag } \\
\text { e share of } \\
\text { companie } \\
\text { s [\%] }\end{array}$ & $\begin{array}{l}\text { Number } \\
\text { of } \\
\text { people } \\
\text { surveye } \\
\text { d } \\
\end{array}$ & $\begin{array}{l}\text { Participation } \\
\text { of respondents } \\
{[\%]}\end{array}$ \\
\hline $\begin{array}{l}\text { Telecommunications } \\
\text { operator }\end{array}$ & 2 & $10 \%$ & 12 & $23 \%$ \\
\hline $\begin{array}{l}\text { TV and internet } \\
\text { provider }\end{array}$ & 1 & $5 \%$ & 4 & $8 \%$ \\
\hline Software - house & 2 & $10 \%$ & 4 & $8 \%$ \\
\hline $\begin{array}{l}\text { Professional service } \\
\text { provider (employee } \\
\text { outsourcing) }\end{array}$ & 1 & $5 \%$ & 8 & $15 \%$ \\
\hline Service company & 2 & $10 \%$ & 4 & $8 \%$ \\
\hline $\begin{array}{l}\text { A technological start- } \\
\text { up }\end{array}$ & 3 & $15 \%$ & 5 & $10 \%$ \\
\hline $\begin{array}{l}\text { Cybersecurity and } \\
\text { software tester }\end{array}$ & 2 & $10 \%$ & 6 & $12 \%$ \\
\hline Data center & 2 & $10 \%$ & 2 & $4 \%$ \\
\hline $\begin{array}{l}\text { Hardware and } \\
\text { software supplier }\end{array}$ & 1 & $5 \%$ & 1 & $2 \%$ \\
\hline Equipment distributor & 1 & $5 \%$ & 1 & $2 \%$ \\
\hline IT systems integrator & 2 & $10 \%$ & 4 & $8 \%$ \\
\hline $\begin{array}{l}\text { Provider of } \\
\text { teletechnical systems }\end{array}$ & 1 & $5 \%$ & 1 & $2 \%$ \\
\hline
\end{tabular}

\section{The first stage of the research}

The first stage of the research revealed that the situation for telecommunications operators seems to be relatively stable, especially taking into account the mass market. However, a drop in satisfaction can be observed among customers due to the increase in complaints regarding the decrease in the quality of services provided. This problem is associated with a significant load on the data transmission network caused by the widespread use of telework. Real-time audio and video transmission requires stable link quality parameters. Access services provided in the mass segment for the most part do not have guaranteed quality, which significantly affects the quality of transmission in the event of an increase in load. Due to overloading, there are also numerous failures, the removal of which is difficult due to imposed restrictions. In business customer segments, there are decreases in revenues related to the freezing of projects and the desire to accumulate cash for corporate clients. Many of the companies that are clients of the operators are currently struggling with the effects of the crisis because they themselves have seen a decline in revenues. Service enterprises that operate in traditional sectors based on 
human work at the service point are the worst in this respect.

Respondents indicate that telecommunications operators have the opportunity to develop domain systems that can be provided in the SaaS model, as various telemedicine systems are indicated here as an example. Operator representatives see this trend as a longterm development that will continue even after the crisis. According to the survey, those employed by operators, systems based on M2M and IoT also create development perspectives, because they allow the elimination of human participation in the implementation of services, e.g. they allow reading a specific parameter remotely. Considering teleconferencing systems, respondents are seeing a slight increase in interest. Among the clients, publicly available tools offered by Microsoft (teams), google (Zoom) or Cisco (Webex) are used rather than ordered dedicated project-implemented systems. In the field of project management, respondents estimated that around $70 \%$ of customer development initiatives were stopped. However, projects focused on rapid digitization of processes have gained in importance.

The employment situation with operators is assessed as relatively stable. However, staff reduction strategies are implemented which originate for reasons other than the COVID-19 crisis. In the area of sales, recruitment has been suspended, and temporary part-time employment is being implemented. Remote work methods were implemented immediately and readiness to change the mode of work according to respondents was high.

In companies that are television and Internet providers, respondents observed similar trends of change. Unlike operators, a temporary increase in the purchase of Internet access services and television packages on the mass market was recorded here. In the business market, however, a significant decrease in revenues was recorded due to the temporary closure of hotels and the reduction in the purchase of television services. Both television providers and operators have developed remote customer service through electronic channels. According to the respondents, the activities were primarily to increase the infoline throughput and minimize the time of customer service in the electronic channel. It should be emphasized that television operators and suppliers are large enterprises, therefore they undertook large-scale image-building activities. For example, campaigns were carried out to spread knowledge about methods of protection against COVID-19, protective equipment was purchased for hospitals, and subsidies of foundations and purposeful fundraisers for the medical sector were organized. Taking into account local activities, computer equipment was made available to children from rural areas, and free Internet access was provided to the poorest.

Subsidiaries of operators are to a large extent service and teletechnical system providers whose mobility has been limited. Respondents emphasized that currently both individual and corporate clients are not willing to contact representatives of enterprises. Thus, service companies and installers are developing ways in which the end users can do some of the work themselves. Similarly, when it comes to equipment, tests are carried out to increase the possibilities of existing models of equipment and reduce the need to replace them. Service companies have modified their strategy and instead of installing, they distribute equipment and other goods (even from outside the ICT sector). On the other hand, in the business segment, due to the large number of telecommunications infrastructure failures, the service department is currently carrying out fewer but more complex orders. Therefore, companies need to acquire more qualified personnel and reduce the number of less qualified service personnel.

According to the respondents, working methods in service companies have hardly changed, while a larger share of work was observed on the basis of remote user support. 
According to respondents, an increase in orders was recorded in software houses. A particularly large number of orders appeared in companies associated with one main customer for many years or in those enterprises that form part of the capital group. Representatives of software-houses assessed the situation and concluded that in the event of an epidemic they received a large number of orders aimed at digitizing and developing electronic channels, as well as upgrading programming to adapt to remote work. Due to the decline in the value of PLN, interest in orders from abroad was noted, especially in software testing companies. In one of the surveyed enterprises, the number of traders selling abroad tripled. Both software developers and testers are used to working remotely, therefore the crisis situation did not significantly affect the way the work was organized. According to the respondents, the number of projects related to cybersecurity was limited. This is quite a surprising conclusion because due to the transfer of a large part of the work of companies to the network, the interest in security should grow. Software development is also associated with creating solutions for monitoring the activity of people in quarantine. The applications are used for social monitoring to determine the potential contact of an infected person with other people. Modeling the course of the epidemic, however, is performed using big data and AI analysis, which is also of interest to software developers. However, start-ups that are largely associated with the development of a specific application are in a difficult situation. Currently, the interest of enterprises in new ideas has significantly decreased, due to the strong commitment to the implementation of routine activities related to counteracting the effects of the crisis.

According to respondents, equipment manufacturers and distributors are currently in a quite difficult situation, because orders for equipment were largely related to the propensity of customers to implement large projects. Currently, development efforts have been limited, which resulted in the freezing of orders. Distribution of equipment is not a highmargin service; therefore, distributors are counting on the possibility of employment reduction. Orders for subscriber and computer equipment are quite stable, which remained relatively intact due mainly to public sector orders. Equipment distributors and manufacturers have established cooperation with IT systems' integrators, striving to stabilize the revenue line by creating cloud-based products. In this way, projects and built environments requiring the purchasing of a large amount of equipment are carried out, while reducing the need for its distributed installation. Data centers benefit from this strategy, which provides disk space for the needs of the systems. Hardware and software suppliers carry out extensive image-oriented activities aimed at providing free tools for the hospital and education sector. This trend has also hit professional service providers, especially the outsourcing of qualified personnel. Due to the suspension of production and the freezing of projects, there was limited demand for outsourcing employees. The contracts concluded are pronounced and employees employed in this form experience considerable uncertainty.

The results of the first stage of the study are collected in Table 3. 
Table 3: Diagnosed changes in ICT enterprises and their environment related to the COVID-19 crisis

\begin{tabular}{|c|c|c|}
\hline Area of change & $\begin{array}{l}\text { Hypothesis: } \\
\text { expected change } \\
\text { trend }\end{array}$ & Description \\
\hline $\begin{array}{lr}\text { Demand } & \text { and } \\
\text { willingness } & \text { to } \\
\text { spend } & \end{array}$ & $\begin{array}{l}\text { Stagnation while } \\
\text { maintaining the } \\
\text { growth of selected } \\
\text { segments }\end{array}$ & $\begin{array}{l}\text { The hypothesis was confirmed with a pessimistic forecast } \\
\text { regarding future changes in revenues. } 40 \% \text { of respondents } \\
\text { reported an increase in revenue, which they treat as } \\
\text { temporary. Ultimately, they expect long-term declines in } \\
\text { the business segment reaching even } 20 \%-30 \% \text {, which is } \\
\text { associated with the pursuit of capital accumulation and the } \\
\text { implementation of crisis plans in clients' enterprises. Only } \\
2 \% \text { of respondents expect an increase in revenues (test } \\
\text { companies). Companies see significant opportunities for } \\
\text { development in foreign markets due to the decrease in the } \\
\text { value of the Polish currency (5\%). }\end{array}$ \\
\hline $\begin{array}{l}\text { Market } \\
\text { opportunities } \\
\text { and development }\end{array}$ & $\begin{array}{l}\text { The emergence of } \\
\text { new market } \\
\text { opportunities. } \\
\text { Interruption of } \\
\text { previously stable } \\
\text { trends }\end{array}$ & $\begin{array}{l}\text { The hypothesis has been confirmed. Among the main } \\
\text { trends in the Industry } 4.0 \text { area, that have been } \\
\text { discontinued, are smart-city solutions (currently city } \\
\text { investments are directed at co-financing hospitals). The } \\
\text { growing importance of ICT enterprises trends will be in: } \\
\text { IoT (71\%), M } 2 \mathrm{M}(24 \%) \text {, specialist services }(13 \%) \text {, AI } \\
(10 \%) \text {, telemedicine }(8 \%) \text {, data protection }(5 \%) \text {, non- } \\
\text { contact systems (4\%), use of robots (4\%) biometric } \\
\text { auditing (2\%). }\end{array}$ \\
\hline $\begin{array}{l}\text { Employment and } \\
\text { demand } \\
\text { specialists }\end{array}$ & $\begin{array}{l}\text { Turbulence in the } \\
\text { employment market }\end{array}$ & $\begin{array}{l}\text { The hypothesis has been confirmed. There was a decrease } \\
\text { in demand for outsourcing employees in the auto-motive } \\
\text { sector }(15 \%) \text {. Entire teams of specialists have appeared on } \\
\text { the market to be taken over by ICT companies in connection } \\
\text { with the freezing of projects }(12 \%) \text { and phenomena such as } \\
\text { reduction of salary or full-time employment }(6 \%) \text {. } \\
\text { Respondents indicate an increase in the amount of current } \\
\text { work and fatigue by telework }(72 \%)\end{array}$ \\
\hline $\begin{array}{l}\text { Implementation } \\
\text { of projects }\end{array}$ & $\begin{array}{l}\text { Changes in the scope } \\
\text { of projects and } \\
\text { portfolios }\end{array}$ & $\begin{array}{l}\text { The hypothesis has been confirmed by way of observation: } \\
\text { freezing of projects in the area of cybersecurity (41\%), } \\
\text { suspension of projects requiring investment in equipment } \\
(31 \%) \text {, reducing the scope of the project }(12 \%) \text {, } \\
\text { recomposition of project portfolios }(10 \%) \text {, increasing the } \\
\text { share of foreign projects }(3 \%)\end{array}$ \\
\hline Company image & $\begin{array}{l}\text { Take action to } \\
\text { combat the epidemic }\end{array}$ & $\begin{array}{l}\text { The hypothesis was confirmed; however, the activities } \\
\text { largely concerned the IT area. The products and services } \\
\text { were made available for free or at preferential prices } \\
(21 \%) \text {, a fundraising campaign was organized to combat } \\
\text { COVID-19 (10\%), programs aimed at supporting e- } \\
\text { education and the medical sector were implemented (8\%). }\end{array}$ \\
\hline $\begin{array}{l}\text { Management and } \\
\text { work methods }\end{array}$ & $\begin{array}{l}\text { Digitization } \\
\text { processes } \\
\text { teleworking }\end{array}$ & $\begin{array}{l}\text { The hypothesis was confirmed, although the way of } \\
\text { working during the epidemic did not differ significantly } \\
\text { from the standards already adopted in ICT enterprises. In } \\
\text { particular, the teleworking system was implemented } \\
(92 \%) \text { and the digitization of internal processes was } \\
\text { deepened (41\%). It was indicated that teleworkers do not } \\
\text { need special methods of supervision and control }(100 \%) \text {. In }\end{array}$ \\
\hline
\end{tabular}




\begin{tabular}{|l|l|l|}
\hline & & $\begin{array}{l}\text { the respondents' opinion, an important element of changes } \\
\text { was the protection of personal data (11\%). }\end{array}$ \\
\hline $\begin{array}{l}\text { Willingness to } \\
\text { implement } \\
\text { changes }\end{array}$ & High readiness & $\begin{array}{l}\text { The hypothesis was confirmed. The ability to implement } \\
\text { changes was rated very high (98\%). The high degree of } \\
\text { enterprise digitization and possession of IT equipment } \\
(100 \%) \text { facilitated adaptation to new conditions. }\end{array}$ \\
\hline
\end{tabular}

\section{The second stage of studies}

The results collected in Table 3 were deepened in the second stage of the study. This stage revealed that in large part respondents perceive the current situation in a pessimistic way, practically freezing most development initiatives. At the same time, $72 \%$ of respondents confirmed that they must take measures aimed at further development and construction of new products and services that respond to the changing market demand. However, over half of the respondents could not name new solutions yet. Most of them used general terms related to the development of a given market area: e.g., development of SaaS solutions $(47 \%)$, expansion of call-center services $(15 \%)$, construction of virtualized environments (15\%) and remote monitoring of own employees and clients $(12 \%)$ or construction of cost control systems (2\%). Respondents were asked to characterize the strategy adopted for the crisis. Unfortunately, for the most part, they were unable to provide detailed answers, rather describing operational activities that were a reaction to emerging problems. The answers included: cost cutting (28\%), reduction of employees' working time $(22 \%)$, freezing of development projects (21\%), resignation from the organization of conferences (15\%), resignation from organization of training, and implementation of on-line activities line (12\%). Among the most important opportunities created in the face of the COVID-19 crisis, representatives of ICT enterprises indicated: international expansion (19\%), resignation from part of the office space due to the development of telework, and the possibility of reducing current costs $(12 \%)$, increasing awareness of the need to digitize processes for external clients, which may lead to market development (11\%), building an offer related to consulting in addition to providing simple services (2\%), and development of new services and specialized products (2\%). Among the biggest threats, the respondents mentioned: loss of liquidity (68\%), loss of sales opportunities for which they had worked for a long time (54\%), loss of work by specialists (21\%), sale of enterprises (14\%), departure of key personnel (8\%), loss of investors (8\%).

Summing up the presented research results, it should be emphasized that they relate to a period of high uncertainty among the studies. In many companies analyzed, detailed results related to the loss of orders were not yet known. Opinions were based primarily on a quantitative analysis of contracts that had been lost, projects that had been suspended, and estimates of market segment transformations that had unexpectedly begun to increase. The first quarter in which the full picture of the effects of the crisis will be known is Q2 2020. At that point, it seems as though it will be valuable to repeat the tests on the same research sample. The conducted studies do not meet the criteria of representativeness, although they may illustrate certain trends in the ICT sector.

\section{Summary}

Due to the changing market conditions associated with the COVID-19 epidemic, enterprises, regardless of the sector in which they operate, must take remedial action. In the case of the ICT sector, which additionally plays the role of a stimulus for the development of other industries, the negative impact of the crisis may have secondary effects on the entire economy. In this context, it is important to attempt to analyze the scope of changes in the sector and to identify ways of dealing with alarming phenomena undertaken by ICT companies. 
The purpose of the article was to attempt to approximate the conditions currently affecting ICT enterprises, and to indicate how enterprises respond to changes. The goal was achieved by analyzing the results of empirical research conducted on a sample of 52 respondents from 20 Polish ICT enterprises. The research method used was an in-depth series of interviews, which allowed us to confirm seven hypotheses.

The main conclusions are not optimistic, because ICT companies are focused on investment reduction and expect similar actions taken by clients. Only some business segments do not show disturbances. It should be emphasized, however, that enterprises are open to seeking new business models based on SaaS. In addition, expansion appears on the international markets as a chance, which seems justified given the low value of the currency. Generally, enterprises are focused on undertaking anti-crisis measures.

A significant limitation of the research was the deep focus of managers from the ICT sector on dealing with the current crisis. In addition, the enterprises did not have detailed data, therefore the presented conclusions are a qualitative assessment of the situation by the management.

The analysis of changes taking place in the ICT sector is an interesting research area that can be continued as economic conditions continue to develop.

\section{Aknowledgment}

The project is financed by the Ministry of Science and Higher Education in Poland under the programme "Regional Initiative of Excellence" 2019 - 2022 project number 015/RID/2018/19 total funding amount 10721040,00 PLN

\section{References}

- Central Statistics Office, Ministry of Finance and Economic Development (2010), Economic and Social Indicators Information and Communication Technologies (ICT) statistics - 2009, Port Louis
- Gartner (2019), “Gartner Market Databook, 3Q19 Update", [Online], [Retrieved march 3, 2020] available on: https://www.gartner.com/en/newsro om/press-releases/2019-10-23gartner-says-global-it-spending-togrow-3point7-percent-in-2020,

- Garcia-Muniz, A. S., Vicante, M.R. (2014), ICT technologies in Europe: A study of technological diffusion and economic growth under network theory', Telecommunications Policy 38 (4), 360-370

- Grodzka, D. (2009), Społeczeństwo informacyjne - idea, programy, badania, 2009 [in:] Biuro Analiz Sejmowych Kancelarii Sejmu, Społeczeństwo informacyjne, Studia Biura Analiz Kancelarii Sejmu 3(19), Wydawnictwo Sejmowe Kancelarii Sejmu., Warszawa

- IDC, International Data Corporation, (2020), Market Perspective report, Impact of Covid-19 on European ICT Market and Ecosystem European Survey, march 2020, [Online], [Retrieved march 3, 2020] available on: https://www.idc.com/getdoc.jsp?cont ainerId=prEUR146133320

- Jasińska, K., Szapiro, T. (2014), Zarządzanie procesami realizacji projektów $w$ sektorze ICT, Wydawnictwo Naukowe PWN, Warszaw

- KIGEiT (2020), Wspólna ankieta DIGITALEUROPE i KIGEiT - wpływ COVID-19 na rynek ICT, Krajowa Izba Gospodarcza Elektroniki i Telekomunikacji, marzec 2020, [Online], [Retrieved march 30, 2020] available

on: https://kigeit.org.pl/2020/03/23/wsp olna-ankieta-digitaleurope-i-kigeitwplyw-covid-19-na-rynek-ict/

- Lombard, D., Globalna wioska cyfrowa. Drugie życie sieci, MT Biznes, 2009

- OECD (2002), Measuring the information economy, Annex 1. The OECD definition of the ICT sector, 2002

- OECD (2011), OECD Information Technology Outlook 2010, OECD Publishing

- $\quad$ PARP (2017), Polska Agencja Rozwoju Przedsiębiorczości, Perspektywy rozwoju polskiej branży ICT do roku 2025, Wydawnictwo PARP, [Online], 
[Retrieved march 7, 2020] avaliable on: https://www.parp.gov.pl/storage/pub lications/pdf/2017_ict_sector_by_2025 _pl.pdf

- PARP (2019), Polska Agencja Rozwoju Przedsiębiorczości, IT/ICT martket in Poland, Wydawnictwo PARP, 2019 [Online], [Retrieved march 12, 2020] avaliable on https://www.trade.gov.pl/pl/f/v/570 995/PPE_PL_IT\%20ICT\%20SECTOR\% 20IN\%20POLAND.pdf]

- Sassi, S., Goaied, M. (2013) , 'Financial development, ICT diffusion and economic growth: Lessons from MENA region', Telecommunications Policy, Volume 37 ( 4-5), 252-261

- Shamim, F. (2007), 'The ICT environment, financial sector and economic growth: a cross-country analysis', Journal of Economis Studies , 34 (4), 352-370

- Schwab, K. (2017) , The Fourth Industrial Revolution, Crown Business: New York, NY, USA

- Stecyk, A. (2009), Wykorzystanie technologii ICT $w$ Polsce - w świetle badań Światowego Forum Ekonomicznego, 'E-mentor, 3 (30), SGH \& Fundacja Promocji i Akredytacji Kierunków Ekonomicznych

- UNSC (2002), United Nations Statistical Commission, ISIC Rev 3.1, International Standard Industrial Classification of All Economic Activities

- WEF (2009), World Economic Forum, ICT for Economic Growth: A Dynamic Ecosystem Driving The Global Recovery

- WEF (2015), World Economic Forum, Deep Shift-Technology Tipping Points and Societal Impact, Global Agenda Council on the Future of Software and Society, World Economic Forum, September

- Zuppo, C.M. (2012), Defining ICT in a boundaryless world: the development of a working hierarchy, 'International Journal of Managing Information Technology' (IJMIT), 4 (3)

- $\quad$ http://ec.europa.eu/archives/ISPO/inf osoc/backg/bangeman.html, [Online], [Retrieved march 15, 2020] access: 16.12.11 